OPEN ACCESS

Edited by:

Olatunde Aremu,

Birmingham City University,

United Kingdom

Reviewed by:

Enver Envi Roshi,

University of Medicine, Tirana, Albania

Mariela Deliverska

Medical University Sofia, Bulgaria

*Correspondence:

Muhammad Zeeshan Shaukat mz.shaukat@ucp.edu.pk

Tehmina Fiaz Qaz

tehmina.qazi@gmail.com

Specialty section:

This article was submitted to

Health Economics,

a section of the journal

Frontiers in Public Health

Received: 30 December 2020

Accepted: 17 May 2021

Published: 15 July 2021

Citation:

Qazi TF, Shaukat MZ, Niazi AAK and

Basit A (2021) Evaluating the

Immediate Response of Country-Wide

Health Systems to the Covid-19

Pandemic: Applying the Gray

Incidence Analysis Model.

Front. Public Health 9:635121.

doi: 10.3389/fpubh.2021.635121

\section{Evaluating the Immediate Response of Country-Wide Health Systems to the Covid-19 Pandemic: Applying the Gray Incidence Analysis Model}

\author{
Tehmina Fiaz Qazi ${ }^{1 *}$, Muhammad Zeeshan Shaukat ${ }^{2 *}$, Abdul Aziz Khan Niazi ${ }^{3}$ and \\ Abdul Basit ${ }^{4}$ \\ ${ }^{1}$ Hailey College of Banking and Finance, University of the Punjab, Lahore, Pakistan, ${ }^{2}$ Faculty of Management Studies, \\ University of Central Punjab, Lahore, Pakistan, ${ }^{3}$ Institute of Business \& Management, University of Engineering and \\ Technology, Lahore, Pakistan, ${ }^{4}$ Lahore Institute of Science and Technology, Lahore, Pakistan
}

The purpose of the study is to evaluate county-wide health systems using the data set of the first wave of the COVID-19 pandemic. The overall design of study comprises a literature review, secondary data, and a mathematical analysis. It is a cross-sectional quantitative study following a deductive approach. It uses the data of the first wave of the COVID-19 pandemic taken from the website of Worldometer as of April 8, 2020. The study uses a gray incidence analysis model (commonly known as Gray Relational Analysis, i.e., GRA) as its research methodology. On the basis of the results of GRA, a classification has been made under a predetermined scheme of ensigns: much better, better, somewhat better, fair, poor, somewhat worse, and worse health systems. There are a total 211 countries that have been divided into the seven aforementioned categories. Findings of the study show that Southern Africa Development Community (SADC) countries fall predominantly under the much better ensign, whereas Organization for Economic Co-operation and Development (OECD), Schengen Area (SA), and/or European Union (EU) countries fall under the worse ensign. Pakistan falls under the ensign of poor. It is an original attempt to evaluate the response of health systems based on real data using a scientific methodology. The study provides valuable information about the health systems of the countries for forming an informed opinion about the health systems herein. The study provides useful new information for stakeholders and a new framework for future research.

Keywords: COVID-19 pandemic, deaths, GRA, gray incidence analysis model, health system, tests, Pakistan

\section{INTRODUCTION}

The COVID-19 pandemic has created serious issues for different countries, particularly those that have weak health systems (1-3). With the outbreak of COVID-19 sustainability, consciousness about healthcare systems has increased, and the need for its performance evaluation has become imperative. The whole world is passing through an abnormal state created by the outbreak of a novel virus COVID-19 from Wuhan, China. Health systems are under extraordinary pressure because of the geometric increase in COVID-19 patients. It is of utmost necessity to evaluate health systems and to revamp them to meet challenges like the current epidemic. The healthcare systems of 
many countries collapsed during the first wave of COVID-19. It has become obligatory to evaluate the healthcare systems of the world afresh, particularly before embarking on a regime of reforms. The question of measurement of performance and comparison of that performance between healthcare systems of several countries has arisen as an offshoot of the COVID-19 pandemic. Answering this question is not that simple; rather, it is complex and difficult. A plethora of research has already been published on healthcare system in general across the globe, and it is important to document that the efforts have been made by different researchers on many counts, e.g., studies like those on the role of pharmacies in health system of Colombia (4), challenges faced by the national healthcare service in Italy (5), the health system of Mount Sinai, US (6), the proactive role of the public health agency of Canada (1), the strengthening of the Mexican healthcare system by addressing the environmental, social, and healthcare issues (7), the healthcare services of the Hubei province of China (8), the challenges to the Bulgarian healthcare system (9), the resilience of the Taiwanese healthcare system (10), the strained Greek healthcare care system (11), eHealth, remote consultation, and the Australia mental health care setting $(12,13)$, the resilience of the Spanish healthcare system (14), the strained healthcare system of Latin America (15), a care center in Pakistan (16), the risk to the Brazilian healthcare system (17), the challenges faced by the healthcare system of sub-Saharan Africa (18), and so on. Most of the countries of the world, including Pakistan, are in the process of rethinking their healthcare systems in order to cope with unforeseen epidemics like COVID-19 (19). All countries are introducing rigorous initiatives by way of establishing laboratories, dedicated quarantine facilities, large-scale awareness campaigns, and smart lockdowns to mitigate the proliferation of coronavirus (20). To address the issue of evaluation of health systems affected by the current pandemic, there is a need to develop a methodology to standardize the measurement of health systems of countries concurrently and simultaneously. Warsame et al. (21) asserted that the development of an epidemic response, and an evaluation approach based on a comprehensive evaluation framework needs to be underpinned. To be specific, the following are the research objectives of this study: (i) to evaluate the health systems of the countries using the data set of the first wave of COVID-19 pandemic; (ii) to determine the gray relational grade of countries' health systems; (iii) to group or classify the countries on the bases of the gray relational grade under pre-determined ensigns in order to provide the basis for an informed opinion to discerners; (iv) to discuss the position of selected countries against their regional blocs; (v) to evaluate the position of Pakistan qua rest of the world in general and among Asian countries in particular; and (vi) to discuss the implications for stakeholders. Where does the healthcare system of a certain country rank during the first wave of the COVID-19 pandemic? This is the prime research question this study will address. The authors considered a range of multi-criteria-decision-making techniques: $A N P$, FANP, AHP, TOPSIS, DEA, GRA, VIKOR, SWARA, ISM, TISM, $M I C M A C, S E M$, and Regression. Keeping in view the nature of the study, GRA (Gray Incidence Analysis Model) was found to be appropriate since it has the capability to accommodate
TABLE 1 | Specification of system variables.

\begin{tabular}{lll}
\hline Code & Variables & Criteria \\
\hline 1 & Total Covid-19 infections & Minimum better \\
2 & New Covid-19 infections & Minimum better \\
3 & Total deaths by Covid-19 infections & Minimum better \\
4 & Total recoveries from Covid-19 infections & Maximum better \\
5 & Active cases of Covid-19 & Minimum better \\
6 & Serious/Critical patients of Covid-19 & Minimum better \\
7 & Tot cases/1M pop of Covid-19 & Minimum better \\
8 & Deaths/1M pop by Covid-19 & Minimum better \\
9 & Total tests of Covid-19 & Maximum better \\
10 & Tests/1M pop of Covid-19 & Maximum better \\
\hline
\end{tabular}

a large set of cross-sections and a multitude of system variables even with missing, insufficient, and/or incomplete data. Therefore, in this study, the GRA method is used to assess the performance of countries' health systems during the COVID19 pandemic. It also has the ability to normalize the data having different units of measurement. This study is worthwhile for regulators of health departments, international institutions, frontline soldiers, researchers, political governments, and society at large. The remainder of this paper is arranged as literature review, theoretical framework, methodology, analysis, results and discussion, and concluding remarks.

\section{LITERATURE REVIEW}

There is no dearth of literature on healthcare systems in general, but, in the current panorama of the COVID-19 pandemic, there is a scarcity of peer-reviewed published research on the current situation. However, there is a lot of published/unpublished upcoming literature about the health systems of different countries (22). In this context, the authors have explored the relevant databases like ScienceDirect, Emarald, JStor, WileyBlackwell, Taylor \& Francis, etc., and have reviewed a significant number of research studies relevant to the phenomenon under study. Highly relevant studies are being reported in order to set the outset of the research: Armocida et al. (5) stated that the National Healthcare Service (responsible for providing health services in regions of Italy) was about to collapse in the Lombardy region of Italy (the most affected region) due to privatization and $\mathrm{a} € 37$ billion financial cut over the period of 2010-2019. Chattu et al. (1) revealed that a Canadian public health agency has proved its global health leadership by way of proactive measures taken to address this worldwide COVID19 outbreak challenge. Chen et al. (8) stressed that pairing assistance (dedicated number of medical personnel to each city depending on the severity of COVID-19) strategy adoption alleviated the pressure on the healthcare system of China, which was a turning point in China's fight against COVID-19. DeSousa et al. (author?) (2) identified 16 physical and mental health challenges being faced by low/middle-income countries and argued that if not addressed, this may get increasingly 
TABLE 2 | Original country wide data set on corona virus.

\begin{tabular}{|c|c|c|c|c|c|c|c|c|c|c|c|}
\hline Sr. & Country & 1 & 2 & 3 & 4 & 5 & 6 & 7 & 8 & 9 & 10 \\
\hline 1 & Afghanistan & 423 & 0 & 14 & 18 & 391 & 0 & 11 & 0.4 & 0 & 0 \\
\hline 2 & Albania & 400 & 17 & 22 & 154 & 224 & 7 & 139 & 8 & 2,989 & 1,039 \\
\hline$\cdots$ & $\ldots \ldots \ldots$ & $\ldots$ & $\ldots$ & $\ldots$ & $\ldots$ & $\ldots$ & $\ldots$ & $\ldots$ & $\ldots$ & $\ldots$ & $\ldots$ \\
\hline$\cdots$ & .......... & $\ldots$ & $\ldots$ & $\cdots$ & $\ldots$ & $\ldots$ & $\ldots$ & $\cdots$ & $\cdots$ & $\ldots$ & $\ldots$ \\
\hline 148 & Pakistan & 4,072 & 37 & 58 & 467 & 3,547 & 25 & 18 & 0.3 & 42,159 & 191 \\
\hline 149 & Palestine & 263 & 2 & 1 & 44 & 218 & 0 & 52 & 0.2 & 15,450 & 3,029 \\
\hline$\cdots$ & $\ldots \ldots \ldots$ & $\ldots$ & $\ldots$ & $\ldots$ & $\ldots$ & $\ldots$ & $\ldots$ & $\ldots$ & $\ldots$ & $\ldots$ & $\ldots$ \\
\hline$\cdots$ & $\ldots \ldots \ldots$ & $\ldots$ & $\ldots$ & $\ldots$ & $\ldots$ & $\ldots$ & $\ldots$ & $\ldots$ & $\ldots$ & $\ldots$ & $\ldots$ \\
\hline 210 & Zambia & 39 & 0 & 1 & 7 & 31 & 0 & 2 & 0.05 & 619 & 34 \\
\hline 211 & Zimbabwe & 11 & 0 & 2 & 0 & 9 & 0 & 0.7 & 0.1 & 371 & 25 \\
\hline
\end{tabular}

Worldometer (2020).

TABLE 3 | Reference sequence and comparable sequences.

\begin{tabular}{|c|c|c|c|c|c|c|c|c|c|c|c|}
\hline Sr. & Country & Total & New & $\begin{array}{c}\text { Total } \\
\text { deaths }\end{array}$ & $\begin{array}{c}\text { Total } \\
\text { recoveries }\end{array}$ & $\begin{array}{l}\text { Active } \\
\text { cases }\end{array}$ & $\begin{array}{l}\text { Serious/ } \\
\text { Critical }\end{array}$ & $\begin{array}{c}\text { Total Cases/ } \\
\text { 1M pop }\end{array}$ & $\begin{array}{l}\text { Deaths/ } \\
1 \mathrm{M} \text { pop }\end{array}$ & $\begin{array}{l}\text { Total } \\
\text { tests }\end{array}$ & $\begin{array}{c}\text { Tests/ } \\
1 \mathrm{M} \text { pop }\end{array}$ \\
\hline 0 & Reference sequences & 1 & 0 & 0 & 77,279 & 1 & 0 & 0 & 0 & $20,82,443$ & 105,458 \\
\hline 1 & Afghanistan & 423 & 0 & 14 & 18 & 391 & 0 & 11 & 0.4 & 0 & 0 \\
\hline 2 & Albania & 400 & 17 & 22 & 154 & 224 & 7 & 139 & 8 & 2,989 & 1,039 \\
\hline$\cdots$ & $\ldots \ldots \ldots$ & $\cdots$ & $\cdots$ & $\cdots$ & $\cdots$ & $\cdots$ & $\cdots$ & $\cdots$ & $\ldots$ & $\ldots$ & $\cdots$ \\
\hline$\cdots$ & $\ldots \ldots \ldots$ & $\cdots$ & $\cdots$ & $\cdots$ & $\cdots$ & $\cdots$ & $\cdots$ & $\cdots$ & $\ldots$ & $\cdots$ & $\ldots$ \\
\hline 148 & Pakistan & 4,072 & 37 & 58 & 467 & 3,547 & 25 & 18 & 0.3 & 42,159 & 191 \\
\hline 149 & Palestine & 263 & 2 & 1 & 44 & 218 & 0 & 52 & 0.2 & 15,450 & 3,029 \\
\hline$\cdots$ & $\ldots \ldots \ldots$ & $\ldots$ & $\ldots$ & $\ldots$ & $\ldots$ & $\ldots$ & $\ldots$ & $\ldots$ & $\ldots$ & $\ldots$ & $\ldots$ \\
\hline$\cdots$ & .......... & $\ldots$ & $\cdots$ & $\cdots$ & $\ldots$ & $\ldots$ & $\ldots$ & $\cdots$ & $\ldots$ & $\ldots$ & $\ldots$ \\
\hline 210 & Zambia & 39 & 0 & 1 & 7 & 31 & 0 & 2 & 0.05 & 619 & 34 \\
\hline 211 & Zimbabwe & 11 & 0 & 2 & 0 & 9 & 0 & 0.7 & 0.1 & 371 & 25 \\
\hline
\end{tabular}

severe over time. Hsieh (10) argued that Taiwan has taken timely initiatives to mitigate the proliferation of COVID-19, including the activation of the Central Epidemic Command Center (CECC) for communication and coordination, supplying surgical masks, issuing national health insurance cards, and postponing schools' classes. Khan et al. (23) collected data from 302 healthcare workers and proclaimed that the majority of Pakistanis are not well-informed and prepared for the COVID19 pandemic, and they are also not familiar with the measures to prevent/control contagion. Kim et al. (24) argued that "The University of Washington Medicine's Post-Acute Care Network" established a three-phase approach (initial, delayed, and surge phases) that helped clinics, hospitals, emergency medical services from becoming overwhelmed and to alleviate the spread of COVID-19 cases. Kretchy et al. (25) concluded that retail pharmacies and community pharmacists are easily accessible and are coming forward to share the burden of the healthcare system in low/middle-income countries. Similarly, Amariles et al. (4) revealed an active role of pharmacy staff and community pharmacy to lessen the burden on the healthcare system. Legido-Quigley et al. (26) claimed that Singapore, Hong Kong, and Japan outlined core dimensions for the development of resilience-oriented healthcare systems, including effective intragovernmental coordination, adaptations, allocations of finances, smooth political environment, availability of treatment, supply of medicine, and routine healthcare services. Legido-Quigley et al. (14) revealed that Spanish healthcare systems efficiently managed the first 6 weeks since the first case was identified, but as time passed, pressure built on the six building block of the Spanish healthcare system (i.e., governance, medicine and equipment, financing, healthcare workers, service delivery, and information). Lorenz et al. (27) argued that the outbreak of COVID-19 and dengue fever have caused great damage to the healthcare system in Brazil; alone, COVID-19 has the potential to swamp the Brazilian healthcare system, and a unified partnership between public and private healthcare systems is thus needed to combat this pandemic. Ma et al. (3) identified potential repercussions of the COVID-19 pandemic on health and surgical care in low/middleincome countries and stated that optimizing resources, providing accurate information/knowledge and training to healthcare workers, and protection are the only means to contain the spread of COVID-19. Menon and Padhy (28) revealed that there are some ethical dilemmas faced by healthcare workers 
TABLE 4 | Normalized comparable sequences.

\begin{tabular}{|c|c|c|c|c|c|c|c|c|c|c|c|}
\hline Sr. & Country & Total & New & $\begin{array}{c}\text { Total } \\
\text { deaths }\end{array}$ & $\begin{array}{c}\text { Total } \\
\text { recoveries }\end{array}$ & $\begin{array}{l}\text { Active } \\
\text { cases }\end{array}$ & $\begin{array}{l}\text { Serious/ } \\
\text { Critical }\end{array}$ & $\begin{array}{c}\text { Tot Cases/1M } \\
\text { pop }\end{array}$ & $\begin{array}{c}\text { Deaths/1M } \\
\text { pop }\end{array}$ & $\begin{array}{l}\text { Total } \\
\text { tests }\end{array}$ & $\begin{array}{c}\text { Tests/1M } \\
\text { pop }\end{array}$ \\
\hline 0 & Reference sequences & 1.00000 & 1.0000 & 1.0000 & 1.00000 & 1.0000 & 1.0000 & 1.0000 & 1.0000 & 1.0000 & 1.0000 \\
\hline 1 & Afghanistan & 0.99895 & 1.0000 & 0.9992 & 0.00023 & 0.9989 & 1.0000 & 0.9987 & 0.9996 & 0.0000 & 0.0000 \\
\hline 2 & Albania & 0.99900 & 0.9964 & 0.9987 & 0.00199 & 0.9994 & 0.9992 & 0.9841 & 0.9920 & 0.0014 & 0.0099 \\
\hline$\cdots$ & $\ldots \ldots \ldots$ & $\cdots$ & $\cdots$ & $\ldots$ & $\cdots$ & $\cdots$ & $\cdots$ & $\ldots$ & $\ldots$ & $\ldots$ & $\ldots$ \\
\hline$\cdots$ & $\ldots \ldots \ldots$ & $\cdots$ & $\cdots$ & $\ldots$ & $\cdots$ & $\cdots$ & $\ldots$ & $\ldots$ & $\cdots$ & $\ldots$ & $\cdots$ \\
\hline 148 & Pakistan & 0.98984 & 0.9922 & 0.9966 & 0.00604 & 0.9903 & 0.9973 & 0.9979 & 0.9997 & 0.0202 & 0.0018 \\
\hline 149 & Palestine & 0.99935 & 0.9996 & 0.9999 & 0.00057 & 0.9994 & 1.0000 & 0.9940 & 0.9998 & 0.0074 & 0.0287 \\
\hline$\cdots$ & .......... & $\cdots$ & $\cdots$ & $\ldots$ & $\cdots$ & $\cdots$ & $\cdots$ & $\ldots$ & $\ldots$ & $\ldots$ & $\ldots$ \\
\hline$\cdots$ & (n....... & $\cdots$ & $\cdots$ & $\cdots$ & $\ldots$ & $\cdots$ & $\ldots$ & $\ldots$ & $\ldots$ & $\ldots$ & $\ldots$ \\
\hline 210 & Zambia & 0.99991 & 1.0000 & 0.9999 & 0.00009 & 0.9999 & 1.0000 & 0.9998 & 1.0000 & 0.0003 & 0.0003 \\
\hline 211 & Zimbabwe & 0.99998 & 1.0000 & 0.9999 & 0.00000 & 1.0000 & 1.0000 & 0.9999 & 0.9999 & 0.0002 & 0.0002 \\
\hline
\end{tabular}

TABLE 5 | Deviation sequences.

\begin{tabular}{|c|c|c|c|c|c|c|c|c|c|c|c|}
\hline Sr. & Country & Total & New & $\begin{array}{l}\text { Total } \\
\text { deaths }\end{array}$ & $\begin{array}{c}\text { Total } \\
\text { recoveries }\end{array}$ & $\begin{array}{l}\text { Active } \\
\text { cases }\end{array}$ & $\begin{array}{l}\text { Serious/ } \\
\text { Critical }\end{array}$ & $\begin{array}{c}\text { Tot Cases/1M } \\
\text { pop }\end{array}$ & $\begin{array}{c}\text { Deaths/1M } \\
\text { pop }\end{array}$ & $\begin{array}{l}\text { Total } \\
\text { tests }\end{array}$ & $\begin{array}{c}\text { Tests/1M } \\
\text { pop }\end{array}$ \\
\hline 0 & Reference sequences & 0.00000 & 0.00000 & 0.00000 & 0.00000 & 0.00000 & 0.00000 & 0.00000 & 0.00000 & 0.00000 & 0.00000 \\
\hline 1 & Afghanistan & 0.00105 & 0.00000 & 0.00082 & 0.99977 & 0.00107 & 0.00000 & 0.00126 & 0.00040 & 1.00000 & 1.00000 \\
\hline 2 & Albania & 0.00100 & 0.00358 & 0.00128 & 0.99801 & 0.00061 & 0.00076 & 0.01591 & 0.00798 & 0.99856 & 0.99015 \\
\hline$\ldots$ & $\ldots \ldots \ldots$ & $\ldots$ & $\ldots$ & $\cdots$ & $\ldots$ & $\ldots$ & $\ldots$ & $\ldots$ & $\ldots$ & $\ldots$ & $\ldots$ \\
\hline$\cdots$ & $\ldots \ldots \ldots$ & $\ldots$ & $\ldots$ & $\cdots$ & $\ldots$ & $\ldots$ & $\ldots$ & $\ldots$ & $\ldots$ & $\ldots$ & $\ldots$ \\
\hline 148 & Pakistan & 0.01016 & 0.00779 & 0.00339 & 0.99396 & 0.00969 & 0.00273 & 0.00206 & 0.00030 & 0.97976 & 0.99819 \\
\hline 149 & Palestine & 0.00065 & 0.00042 & 0.00006 & 0.99943 & 0.00059 & 0.00000 & 0.00595 & 0.00020 & 0.99258 & 0.97128 \\
\hline$\cdots$ & ......... & $\cdots$ & $\cdots$ & $\cdots$ & $\cdots$ & $\cdots$ & $\ldots$ & $\cdots$ & $\cdots$ & $\ldots$ & $\cdots$ \\
\hline$\cdots$ & ........... & $\ldots$ & $\cdots$ & $\cdots$ & $\cdots$ & $\ldots$ & $\ldots$ & $\cdots$ & $\ldots$ & $\cdots$ & $\ldots$ \\
\hline 210 & Zambia & 0.00009 & 0.00000 & 0.00006 & 0.99991 & 0.00008 & 0.00000 & 0.00023 & 0.00005 & 0.99970 & 0.99968 \\
\hline 211 & Zimbabwe & 0.00002 & 0.00000 & 0.00012 & 1.00000 & 0.00002 & 0.00000 & 0.00008 & 0.00010 & 0.99982 & 0.99976 \\
\hline
\end{tabular}

even in developed countries and offered some suggestions to trounce them. Mukhtar (29) showed that well-being and mental health care are building blocks of the healthcare system, whereas social distancing/isolation and quarantine are causing potential mental health issues that need to be addressed. Rana et al. (16) explained that, being a lower-middle country, Pakistan has a poor healthcare system wherein the budget allocated to health is only $1 \%$ of the GDP. Roder-DeWan (18) argued that lowincome countries are hardly able to achieve fewer than half of the elements indispensable for a high-quality healthcare system than that of high-income countries. Telemedicine and telehealth are a fast-emerging concept of health system during the period of COVID-19 to ensure the effectiveness of isolation/social distancing, helping service provision, tracking, tracing, and testing of COVID-19 cases (30-35). After the review of studies like the aforementioned, it has become imperative that we develop a theoretical framework to evaluate healthcare systems at the country level.

\section{THEORETICAL FRAMEWORK}

Theories help to explain, predict, understand phenomena, and, sometimes, to challenge or to extend our existing knowledge within the boundaries of given assumptions (36). All that is necessary to use our knowledge and understanding in more informed and effective ways (37). A theoretical framework is used to limit the scope of the relevant data. The selection of a theory depends on its appropriateness, ease of application, and explanatory power. Gray system theory is found to be appropriate in this study keeping in view the objectives of the study and research question under investigation. In order to enhance the clarity and interpretability of results, authors have extended the theoretical framework by way of introducing the system of ensigns. To evaluate the phenomena critically, it is vital to connect to the existing knowledge. The framework also helps to articulate the theoretical assumptions and to identify the limits of results' generalizations. This study uses a theoretical framework to limit the scope of the relevant data by focusing on specific variables and defining them [framework] so that researcher may analyze and interpret the data gathered. The framework also facilitates the understanding of concepts and variables according to given definitions and builds new knowledge by validating or challenging theoretical assumptions (37). The authors have selected the following variables to get on the framework of the study (Table 1). 
TABLE 6 | Gray relational co-efficient.

\begin{tabular}{|c|c|c|c|c|c|c|c|c|c|c|c|}
\hline Sr. & Country & Total & New & $\begin{array}{c}\text { Total } \\
\text { deaths }\end{array}$ & $\begin{array}{c}\text { Total } \\
\text { recoveries }\end{array}$ & $\begin{array}{l}\text { Active } \\
\text { cases }\end{array}$ & $\begin{array}{l}\text { Serious/ } \\
\text { Critical }\end{array}$ & $\begin{array}{c}\text { Tot Cases/1M } \\
\text { pop }\end{array}$ & $\begin{array}{c}\text { Deaths/1M } \\
\text { pop }\end{array}$ & $\begin{array}{l}\text { Total } \\
\text { tests }\end{array}$ & $\begin{array}{c}\text { Tests/1M } \\
\text { pop }\end{array}$ \\
\hline 0 & Reference Sequences & 1.00000 & 1.00000 & 1.00000 & 1.00000 & 1.00000 & 1.00000 & 1.00000 & 1.00000 & 1.00000 & 1.00000 \\
\hline 1 & Afghanistan & 0.99790 & 1.00000 & 0.99837 & 0.33339 & 0.99787 & 1.00000 & 0.99749 & 0.99920 & 0.33333 & 0.33333 \\
\hline 2 & Albania & 0.99801 & 0.99289 & 0.99744 & 0.33378 & 0.99878 & 0.99848 & 0.96917 & 0.98428 & 0.33365 & 0.33554 \\
\hline$\cdots$ & $\ldots \ldots \ldots$ & $\ldots$ & $\ldots$ & $\ldots$ & $\ldots$ & $\cdots$ & $\cdots$ & $\cdots$ & $\ldots$ & $\cdots$ & $\ldots$ \\
\hline$\cdots$ & $\ldots \ldots \ldots$ & $\cdots$ & $\ldots$ & $\cdots$ & $\ldots$ & $\ldots$ & $\cdots$ & $\cdots$ & $\ldots$ & $\cdots$ & $\cdots$ \\
\hline 148 & Pakistan & 0.98008 & 0.98465 & 0.99327 & 0.33468 & 0.98099 & 0.99458 & 0.99590 & 0.99940 & 0.33789 & 0.33374 \\
\hline 149 & Palestine & 0.99869 & 0.99916 & 0.99988 & 0.33346 & 0.99882 & 1.00000 & 0.98824 & 0.99960 & 0.33499 & 0.33984 \\
\hline$\cdots$ & ......... & $\cdots$ & $\cdots$ & $\cdots$ & $\cdots$ & $\cdots$ & $\cdots$ & $\cdots$ & $\cdots$ & $\cdots$ & $\cdots$ \\
\hline$\cdots$ & $\ldots \ldots \ldots$ & $\cdots$ & $\ldots$ & $\cdots$ & $\cdots$ & $\cdots$ & $\ldots$ & $\ldots$ & $\ldots$ & $\ldots$ & $\ldots$ \\
\hline 210 & Zambia & 0.99981 & 1.00000 & 0.99988 & 0.33335 & 0.99984 & 1.00000 & 0.99954 & 0.99990 & 0.33340 & 0.33340 \\
\hline 211 & Zimbabwe & 0.99995 & 1.00000 & 0.99977 & 0.33333 & 0.99996 & 1.00000 & 0.99984 & 0.99980 & 0.33337 & 0.33339 \\
\hline
\end{tabular}

The variables of social sciences normally have three types of acceptable characteristics. The first type of variable may be maximum better, the second type of variable might have characteristics of minimum better, and the third type of variable may have characteristics of target the better. Close observation of the variables reveals that variables $1,2,3,5,6,7$, and 8 possess the characteristic of minimum better, whereas variables 4,9 , and 10 possess the characteristic of maximum better. With this framework, the authors opted to use the Gray Incidence Analysis Model as a solution methodology.

\section{METHODOLOGY}

This study follows positivist philosophy and deductive approach. It is a cross-sectional research study that uses data of the first wave of COVID-19 pandemic taken from the website of Worldometer as of April 8, 2020. It uses the Gray Incidence Analysis Model (commonly known as Gray Relational Analysis or simply GRA). It is a unique mathematical approach selected from the array of multi-criteria-decision-making techniques. This technique is frequently employed to use an incomplete and impure set of data for analyzing relations of a multitude of variables. It has prevails on statistical techniques like regression analysis because of their limitations and demand for large amounts of data for generating meager results (38). GRA progresses stepwise (39-43). The first step, in this model, is obtaining data; the second is the creation of a reference series; the third is the generation of a comparable sequence; the fourth is the generation of a reference series; the fifth is the generation of a normalized matrix; the sixth is the calculation of a deviation sequence; the seventh is the creation of absolute values with a difference in the reference sequence and comparable sequence; the eighth is the establishment of a co-efficient matrix of a gray relation system; the ninth is the computation of a gray relational grade; and the tenth step is the arrangement of these in a descending order. The method has been augmented with a classification of the cross-sections using the method of ensigns introduced by the authors. In this method, first, the operational definitions of ensign groups have been generated on the basis of distributing the scale into seven ensigns.
TABLE 7 | Gray relational grades.

\begin{tabular}{llc}
\hline Sr. & Country & Gray relational grade \\
\hline 0 & Reference sequences & 1.0000 \\
1 & Afghanistan & 0.7991 \\
2 & Albania & 0.7942 \\
$\ldots$ & $\ldots \ldots \ldots .$. & $\ldots$ \\
$\ldots$ & $\ldots \ldots \ldots \ldots$ & $\ldots$ \\
148 & Pakistan & 0.7935 \\
149 & Palestine & 0.7993 \\
$\ldots$ & $\ldots \ldots \ldots \ldots$ & $\ldots$ \\
$\ldots$ & $\ldots \ldots \ldots .$. & $\ldots$ \\
210 & Zambia & 0.7999 \\
211 & Zimbabwe & 0.7999 \\
\hline
\end{tabular}

\section{Applying Gray Incidence Analysis Model}

The following steps of GRA were used to access the best performer among different countries of the world.

Step 1: We created a data set (Table 2) and established a decision matrix of data set denoted in the following formula:

$$
x_{i}(k)=\left[\begin{array}{ccc}
x_{1}(1) x_{1}(2) & \cdots & x_{1}(m) \\
\vdots & \ddots & \vdots \\
x_{n}(1) x_{n}(2) & \cdots & x_{n}(m)
\end{array}\right]
$$

Step 2: We created a reference series and comparison matrix (Table 3) using a classical rule of reference and comparison.

Step 3: We created a normalized matrix (Table 4) using the following formulas for maximum better and minimum better.

For maximum better:

$$
x_{i}^{*}(k)=\frac{x_{i}^{(0)}(k)-\min x_{i}^{(0)}(k)}{\max x_{i}^{(o)}(k)-\min x_{i}^{(o)}(k)}
$$

For minimum better:

$$
x_{i}^{*}(k)=\frac{\max x_{i}^{(o)}(k)-x_{i}^{(0)}(k)}{\max x_{i}^{(0)}(k)-\min x_{i}^{(0)}(k)}
$$


TABLE 8 | Scheme of grouping the countries under different ensigns on the basis of gray relational grades of health systems.

\begin{tabular}{|c|c|c|}
\hline Sr. & Ensign & Description \\
\hline 1 & Much better & $\begin{array}{l}\text { Countries having a gray relational grade ranging from } 0.8203 \text { to } 0.7999 \text { are considered as having an excellent health system (top } \\
\text { thirty countries). }\end{array}$ \\
\hline 2 & Better & Countries having a gray relational grade ranging from 0.7999 to 0.7994 are considered as having a very good health system. \\
\hline 3 & Somewhat better & Countries having a gray relational grade ranging from 0.7994 to 0.7980 are considered as having a good health system. \\
\hline 4 & Fair & Countries having a gray relational grade ranging from 0.7978 to 0.7947 are considered as having a satisfactory health system. \\
\hline 5 & Poor & Countries having a gray relational grade ranging from 0.7945 to 0.7890 are considered as having a weak health system. \\
\hline 6 & Somewhat worse & Countries having a gray relational grade ranging from 0.7889 to 0.7724 are considered as having a very weak health system. \\
\hline 7 & Worse & Countries having a gray relational grade ranging from 0.7723 to 0.4854 are considered as having the worst health system. \\
\hline
\end{tabular}

For example, for Afghanistan, "smaller is the better"

$$
\begin{aligned}
x_{1}^{*}(1)= & \frac{\max x_{1}^{0}(1)-x_{1}^{0}(1)}{\max x_{1}^{0}(1)-\min x_{1}^{o}(1)}=\frac{4005249-423}{4005249-1} \\
& =0.999895
\end{aligned}
$$

Step 4: We calculated deviation sequences (Table 5) by using the following formula:

$$
\Delta_{0}(\gamma)=\left|x_{0}(\gamma)-x_{1}(\gamma)\right|
$$

For example, for Albania

$$
\triangle_{02}(2)=\left|x_{0}^{*}(2)-x_{2}^{*}(2)\right|=|1-0.9964|=0.0036
$$

Step 5: The Gray relational co-efficient is calculated (Table 6) by using the following formula based on values of normalized sequences. Term $\xi$ is the distinguishing co-efficient between 0 and 1 , the usual value of which is 0.5 in literature.

$$
\begin{aligned}
\gamma\left[x_{0}^{*}(k), x_{i}^{*}(k)\right]= & \frac{\Delta_{\min }+\xi \Delta_{\max }}{x_{0 i}(k)+\xi \Delta_{\max }}, 0<\gamma\left[x_{o}^{*}(k), x_{i}^{*}(k)\right] \\
& \leq 1
\end{aligned}
$$

For example, for Albania,

$$
\begin{aligned}
\gamma\left[x_{0}^{*}(2), x_{2}^{*}(2)\right]= & \frac{\Delta_{\min +\xi} \Delta_{\max }}{\Delta_{2}(2)+\xi_{\max }}=\frac{0+(0.5) \times 1}{0.0036+(0.5) \times 1} \\
& =0.9928
\end{aligned}
$$

Step 6: The weighted sum of gray relational co-efficient (Gray Relational Grade) is calculated (Table 7) by using the following formula:

$$
\begin{aligned}
& \gamma\left(x_{0}{ }^{*}, x_{i}{ }^{*}\right)=\sum_{k=1}^{n} \beta_{k} \gamma\left[x_{0}{ }^{*}(k), x_{i}{ }^{*}(k)\right] \\
& \sum_{k=1}^{n} \beta_{k}=1
\end{aligned}
$$

For example, for Albania,

$$
\begin{aligned}
& \gamma\left(x_{0}{ }^{*}, x_{2}^{*}\right)=\sum_{k=1}^{n} \beta_{k} \gamma\left[x_{0}{ }^{*}(2), x_{2}{ }^{*}(k)\right] \\
& =0.10 \times\left(\begin{array}{c}
0.9980+0.9929+0.9974+0.3338+0.9988 \\
+0.9985+0.9692+0.9843+0.3337+0.3355
\end{array}\right) \\
& =0.7942
\end{aligned}
$$

The authors have introduced the method of ensigns to represent the gray relational ranks of the countries. The ensigns were taken on the basis of the pattern of the ordinal scale, including much better, better, somewhat better, fair, poor, somewhat worse, and worse. The operational definitions of these ensigns are given in Table 8. This method has been introduced to logically represent and interpret the results of gray relational analysis particularly that of the ranks of the countries qua other counterparts. This also facilitates the provision of insight into the different blocs of countries currently existing in the world. In fact, there are 211 total countries under investigation and the scale of ensigns consists of seven items, therefore, $\sim 30$ countries are categorized in each bracket of an ensign. The bracket of gray relational grade has also been mentioned against each scale item to make the information more objective and meaningful.

Readers will find ensigns information significantly helpful in making an informed opinion about a countries' and/or blocs' health systems.

\section{RESULTS AND DISCUSSION}

\section{Results}

We measured the performance of healthcare systems in countries and compared those performances with others as an offshoot of the COVID-19 pandemic. This is important because the countries are planning to revisit the architecture of their healthcare systems, and the answer is not that simple. The healthcare systems of many countries collapsed as a result of the first wave of COVID-19, and, therefore, it is vital to evaluate health systems before any revamping. Hence the aim of this study is to evaluate healthcare systems in different countries, including Pakistan, and compare them against each other. The study uses Gray Relational Analysis (GRA) as its methodology to evaluate the system and it uses secondary data from the website of Worldometer (44). The study thus provides understanding to readers in terms of the capability of healthcare systems in different countries in responding to pandemics like COVID-19. The authors gathered a significant number of articles, reports, statistical bulletins, and official documents from authoritative websites and examined the findings to set the context of the study. Results of the analysis are given in Table 9.

Using the gray relational analysis (i.e., mathematical technique of data analysis with the capability of handling a multitude of 
TABLE 9 | Results of gray relational analysis.

\begin{tabular}{|c|c|c|c|c|c|c|c|c|}
\hline Country & $\begin{array}{l}\text { Gray relational } \\
\text { grades }\end{array}$ & Rank & Country & $\begin{array}{l}\text { Gray relational } \\
\text { grades }\end{array}$ & Rank & Country & $\begin{array}{c}\text { Gray relational } \\
\text { grades }\end{array}$ & Rank \\
\hline Reference sequences & 1.0000 & 0 & Maldives & 0.7992 & 70 & Greece & 0.7910 & 141 \\
\hline Faeroe Islands & 0.8203 & 1 & Jordan & 0.7992 & 72 & Turks and Caicos & 0.7909 & 143 \\
\hline Vietnam & 0.8010 & 2 & Belize & 0.7991 & 73 & $\begin{array}{l}\text { Bosnia and } \\
\text { Herzegovina }\end{array}$ & 0.7909 & 144 \\
\hline New Caledonia & 0.8004 & 4 & Hong Kong & 0.7989 & 75 & Moldova & 0.7904 & 146 \\
\hline Bhutan & 0.8002 & 5 & Burkina Faso & 0.7989 & 76 & Kuwait & 0.7898 & 147 \\
\hline UAE & 0.8002 & 6 & Greenland & 0.7988 & 77 & Singapore & 0.7894 & 148 \\
\hline Nepal & 0.8000 & 7 & El Salvador & 0.7987 & 78 & India & 0.7893 & 149 \\
\hline Papua New Guinea & 0.8000 & 8 & Azerbaijan & 0.7987 & 79 & Belarus & 0.7890 & 150 \\
\hline Timor-Leste & 0.8000 & 13 & Cuba & 0.7984 & 84 & Saudi Arabia & 0.7886 & 154 \\
\hline Chad & 0.8000 & 14 & Caribbean Netherlands & 0.7984 & 85 & Falkland Islands & 0.7884 & 155 \\
\hline Uganda & 0.8000 & 15 & Uzbekistan & 0.7983 & 86 & Aruba & 0.7883 & 156 \\
\hline MS Zaandam & 0.8000 & 16 & Bolivia & 0.7983 & 87 & Dominican Republic & 0.7882 & 157 \\
\hline Tanzania & 0.8000 & 17 & Saint Lucia & 0.7983 & 88 & Croatia & 0.7881 & 158 \\
\hline Botswana & 0.8000 & 18 & South Africa & 0.7981 & 89 & Ukraine & 0.7881 & 159 \\
\hline Sudan & 0.7999 & 19 & Georgia & 0.7980 & 90 & St. Barth & 0.7878 & 160 \\
\hline CAR & 0.7999 & 20 & \multicolumn{2}{|r|}{ Fair } & & Serbia & 0.7875 & 161 \\
\hline Myanmar & 0.7999 & 21 & Brunei & 0.7978 & 91 & Mayotte & 0.7867 & 162 \\
\hline Malawi & 0.7999 & 22 & Iraq & 0.7978 & 92 & Malaysia & 0.7863 & 163 \\
\hline Zambia & 0.7999 & 30 & Bangladesh & 0.7973 & 100 & Iceland & 0.7825 & 171 \\
\hline \multicolumn{2}{|c|}{ Better } & & Costa Rica & 0.7973 & 101 & Poland & 0.7821 & 172 \\
\hline Haiti & 0.7999 & 31 & Kyrgyzstan & 0.7972 & 102 & Estonia & 0.7811 & 173 \\
\hline Benin & 0.7999 & 32 & Bahrain & 0.7971 & 103 & Mexico & 0.7811 & 174 \\
\hline Namibia & 0.7999 & 33 & Trinidad and Tobago & 0.7971 & 104 & Finland & 0.7796 & 175 \\
\hline Taiwan & 0.7999 & 34 & Curaçao & 0.7970 & 105 & Qatar & 0.7794 & 176 \\
\hline Equatorial Guinea & 0.7999 & 35 & French Polynesia & 0.7968 & 106 & Panama & 0.7764 & 177 \\
\hline Gambia & 0.7999 & 36 & Bulgaria & 0.7967 & 107 & Saint Martin & 0.7745 & 178 \\
\hline Libya & 0.7999 & 37 & Uruguay & 0.7966 & 108 & Norway & 0.7738 & 179 \\
\hline Western Sahara & 0.7998 & 38 & Dominica & 0.7963 & 109 & Montserrat & 0.7724 & 180 \\
\hline Mongolia & 0.7998 & 39 & Tunisia & 0.7963 & 110 & \multicolumn{3}{|c|}{ Worse } \\
\hline Cambodia & 0.7998 & 40 & Saint Kitts and Nevis & 0.7962 & 111 & Isle of Man & 0.7723 & 181 \\
\hline Ethiopia & 0.7998 & 41 & Saint Pierre Miquelon & 0.7962 & 112 & Russia & 0.7715 & 182 \\
\hline Eswatini & 0.7998 & 42 & Djibouti & 0.7957 & 113 & Romania & 0.7708 & 183 \\
\hline Mali & 0.7998 & 43 & Oman & 0.7956 & 114 & Brazil & 0.7702 & 184 \\
\hline Liberia & 0.7998 & 44 & Anguilla & 0.7956 & 115 & Liechtenstein & 0.7690 & 185 \\
\hline Eritrea & 0.7998 & 45 & Colombia & 0.7955 & 116 & Gibraltar & 0.7689 & 186 \\
\hline Rwanda & 0.7997 & 46 & Lebanon & 0.7955 & 117 & Canada & 0.7679 & 187 \\
\hline
\end{tabular}


TABLE 9 | Continued

\begin{tabular}{|c|c|c|c|c|c|c|c|c|}
\hline Country & $\begin{array}{c}\text { Gray relational } \\
\text { grades }\end{array}$ & Rank & Country & $\begin{array}{c}\text { Gray relational } \\
\text { grades }\end{array}$ & Rank & Country & $\begin{array}{c}\text { Gray relational } \\
\text { grades }\end{array}$ & Rank \\
\hline Togo & 0.7997 & 47 & Argentina & 0.7949 & 118 & Israel & 0.7641 & 188 \\
\hline Nigeria & 0.7997 & 48 & Bahamas & 0.7948 & 119 & Monaco & 0.7635 & 189 \\
\hline Madagascar & 0.7996 & 49 & Mauritius & 0.7947 & 120 & Channel Islands & 0.7631 & 190 \\
\hline Sao Tome and Principe & 0.7996 & 50 & \multicolumn{2}{|r|}{ Poor } & & Ireland & 0.7620 & 191 \\
\hline Guinea & 0.7996 & 51 & Latvia & 0.7945 & 121 & Sint Maarten & 0.7610 & 192 \\
\hline Guatemala & 0.7996 & 52 & French Guiana & 0.7944 & 122 & Denmark & 0.7574 & 193 \\
\hline Fiji & 0.7996 & 53 & Morocco & 0.7943 & 123 & Austria & 0.7495 & 194 \\
\hline Gabon & 0.7996 & 54 & Albania & 0.7942 & 124 & Luxembourg & 0.7437 & 195 \\
\hline Guinea-Bissau & 0.7996 & 55 & New Zealand & 0.7940 & 125 & Vatican City & 0.7333 & 196 \\
\hline Congo & 0.7995 & 56 & Algeria & 0.7940 & 126 & Turkey & 0.7319 & 197 \\
\hline DRC & 0.7995 & 57 & Australia & 0.7939 & 127 & Portugal & 0.7301 & 198 \\
\hline Venezuela & 0.7995 & 58 & Pakistan & 0.7935 & 128 & Sweden & 0.7221 & 199 \\
\hline Senegal & 0.7995 & 59 & Barbados & 0.7935 & 129 & Andorra & 0.7061 & 200 \\
\hline Diamond Princess & 0.7994 & 60 & Japan & 0.7932 & 130 & Switzerland & 0.7030 & 201 \\
\hline \multicolumn{2}{|c|}{ Somewhat better } & & Hungary & 0.7925 & 131 & San Marino & 0.6712 & 202 \\
\hline Kenya & 0.7994 & 61 & S. Korea & 0.7925 & 132 & Germany & 0.6709 & 203 \\
\hline Ghana & 0.7994 & 62 & Thailand & 0.7923 & 133 & Netherlands & 0.6681 & 204 \\
\hline Niger & 0.7993 & 63 & Peru & 0.7923 & 134 & UK & 0.6630 & 205 \\
\hline Sri Lanka & 0.7993 & 64 & Malta & 0.7922 & 135 & Belgium & 0.6494 & 206 \\
\hline Ivory Coast & 0.7993 & 65 & Antigua and Barbuda & 0.7919 & 136 & Iran & 0.6255 & 207 \\
\hline Cabo Verde & 0.7993 & 66 & Cyprus & 0.7918 & 137 & USA & 0.5785 & 208 \\
\hline Jamaica & 0.7993 & 67 & Lithuania & 0.7916 & 138 & France & 0.5773 & 209 \\
\hline Palestine & 0.7993 & 68 & Réunion & 0.7912 & 139 & Italy & 0.5661 & 210 \\
\hline Paraguay & 0.7992 & 69 & Montenegro & 0.7911 & 140 & Spain & 0.4854 & 211 \\
\hline
\end{tabular}

variables, cases, and time periods), the study has characterized 211 countries of the world into seven different categories (Table 8). From the result of GRA, it can be learned that there are a total of 30 countries categorized as countries having a much better healthcare system, most of which are member countries of the Southern Africa Development Community (SADC); 30 countries are under the better ensign, most of which are member countries of the West African Economic and Monetary Union (WAEMU); 30 are under the ensign of somewhat better, most of which are member countries of Caribbean Community and Common Market (CARICOM); 30 are under the ensign of fair, most of which are member countries of Arabian Countries (AC); 30 are under the ensign of poor, most of which are member countries of Organization for Economic Co-operation and Development (OECD); 30 are under the ensign of somewhat worse, most of which are member countries of the Organization for Economic Co-operation and Development (OECD); and 30 are under the ensign of worse, most of which are member countries of the Organization for Economic Co-operation and Development (OECD), Schengen Area (SA), and/or European Union (EU). Pakistan fall under the ensign of poor, therefore have a weak health system.

\section{Discussion}

The purpose of the study is to evaluate the health systems at the country level using GRA. The results are classified under a predetermined scheme of ensigns. It is different on many counts from what contemporary literature says in terms of the composite measurement matrix, number of countries, methodology, data set, context, and classification. Traditional studies usually provide statistical analysis with very limited insights. This finding is consistent with on-ground realities. From the result of the study, it can be learned that the healthcare system of advanced countries, i.e., UK, USA, France, Denmark, etc. (almost whole western Europe/Schengen area/OECD), has a very poor response to the shock of COVID-19 pandemic, which is in contrast to the myth that these countries have the best healthcare systems in the world. In this way, the result of the study provides some evidence that it is the other way around. Pakistan's healthcare system, though poor, still ranks above most of the advanced countries as far as the response to the first shock of the COVID-19 pandemic is concerned (Table 9).

\section{CONCLUDING REMARKS}

With the outbreak of COVID-19, consciousness about the sustainability of healthcare systems has increased, and there has been a marked call for the need to evaluate its performance. The whole world is passing through an abnormal condition created with the outbreak of the novel coronavirus. Healthcare systems are under extraordinary pressure. It is of utmost 
necessity to evaluate healthcare systems and to revamp them to meet challenges like the current epidemic. The healthcare systems of many countries collapsed during the first wave of COVID-19. It has become imperative to evaluate the healthcare systems of the world afresh, particularly before embarking on the regime of any reforms. The purpose of the study was to evaluate the health systems of all countries. The study also aimed to evaluate Pakistan's healthcare system against that of the rest of the world. The overall design of the study comprises literature reviews, secondary data, and mathematical analysis. It is a cross-sectional quantitative study following a deductive approach. The study uses Gray Relational Analysis (GRA) as its research methodology. The findings of the study show that there are 30 countries categorized as countries having much better health systems, most of which are member countries of the Southern Africa Development Community (SADC); 30 under the better ensign, most of which are member countries of West African Economic and Monetary Union (WAEMU); 30 are under the ensign of somewhat better, most of which are member countries of the Caribbean Community and Common Market (CARICOM); 30 are under the ensign of fair, most of which are member countries of Arabian Countries (AC); 30 are under the ensign of poor, most of which are member countries of the Organization for Economic Co-operation and Development (OECD); 30 are under the ensign of somewhat worse, most of which are member countries of Organization for Economic Co-operation and Development (OECD), and 30 are under the ensign of worse, most of which are member countries of the Organization for Economic Co-operation and Development (OECD), Schengen Area (SA), and/or European Union (EU). Pakistan falls under the ensign of poor and therefore has a weak healthcare system. The study revealed several practical and theoretical implications. The study has made several contributions to existing literature. It contributes firsthand information about healthcare systems, such as where a country stands as against reference values. It contributed

\section{REFERENCES}

1. Chattu VK, Adisesh A, Yaya S. Canada's role in strengthening global health security during the COVID-19 pandemic. Glob Health Res Policy. (2020) 5:1-3. doi: 10.1186/s41256-020-00146-3

2. De Sousa A, Mohandas E, Javed A. Psychological Interventions during COVID-19: challenges for low and middle income countries. Asian J Psychiatry. (2020) 51:102128. doi: 10.1016/j.ajp.2020.102128

3. Ma X, Vervoort D, Reddy CL, Park KB, Makasa E. Emergency and essential surgical healthcare services during COVID-19 in lowand middle-income countries: a perspective. Int J Surg. (2020) 79:43-6. doi: 10.1016/j.ijsu.2020.05.037

4. Amariles P, Ledezma-Morales M, Salazar-Ospina A, Hincapié-García JA. How to link patients with suspicious COVID-19 to health system from the community pharmacies? A route proposal. Res Soc Administr Pharm. (2020) 17:1988-9. doi: 10.1016/j.sapharm.2020.03.007

5. Armocida B, Formenti B, Ussai S, Palestra F, Missoni E. The Italian health system and the COVID-19 challenge. Lancet Public Health. (2020) 5:e253. doi: 10.1016/S2468-2667(20)30074-8

6. Buckley A, Bianco A, Stone J. Universal testing of patients and their support persons for COVID-19 when presenting for admission to Labor and Delivery gray relational grades and ranks assigned to every country using a multitude of variables. It also contributed by way of classification of healthcare systems into groups under different ensigns to making the results more simple. It provides a potential framework to guide academics and practitioners for future research. The study improves the understanding of concerned people about healthcare systems. Regulators and management can gain understanding from this study for policy decisions. The study builds awareness on systemic issues. The study also has some limitations, and it is worthwhile to mention these limitations in order to achieve clarity. Firstly, it is a crosssectional study, and future studies may be longitudinal, using time series/panel data. Secondly, the study used a data set from the Worldometer website as of April 8, 2020; therefore, the generalizability of results is limited accordingly. Future studies may use different data sets (e.g., data of the WHO, WDI, etc.) in the same theoretical scheme to confirm/validate/substantiate the results. Thirdly, this study uses GRA the hierarchicalization technique, and there are other techniques for this purpose as well, e.g., RIDIT, AHP, TOPSIS, SWARA, VIKOR, and ISM, and future studies may thus use these methodologies. Finally, we have given equal weight to all variables; this may be changed, and future researchers may use AHP, expert opinions, or the entropy method.

\section{DATA AVAILABILITY STATEMENT}

The raw data supporting the conclusions of this article will be made available by the authors, without undue reservation.

\section{AUTHOR CONTRIBUTIONS}

MS initiated the idea and worked on gray analysis. TQ worked on the relevant literature of the topic. AK collected the data and performed the analyses. AB worked on the write up. All authors contributed to the article and approved the submitted version. within the Mount Sinai Health System. Am J Obstet Gynecol MFM. (2020) 2:100147. doi: 10.1016/j.ajogmf.2020.100147

7. de León-Martínez LD, Palacios-Ramírez A, Rodriguez-Aguilar M, Flores-Ramírez R. Critical review of social, environmental and health risk factors in the Mexican indigenous population and their capacity to respond to the COVID-19. Sci Total Environ. (2020) 733:139357. doi: 10.1016/j.scitotenv.2020.139357

8. Chen T, Wang Y, Hua L. "Pairing assistance": the effective way to solve the breakdown of health services system caused by COVID-19 pandemic. Int J Equity Health. (2020) 19:1-4. doi: 10.1186/s12939-02001190-8

9. Dzhafer N, Papathanasiou J. Compassionate drug use: an imperative challenge for Bulgarian health system during COVID-19. Health Policy Technol. (2020) 9:274-5. doi: 10.1016/j.hlpt.2020.05.001

10. Hsieh VCR. Putting resiliency of a health system to the test: COVID-19 in Taiwan. J Formosan Med Assoc. (2020) 119:8845. doi: 10.1016/j.jfma.2020.03.002

11. Kapetanakis EI, Tomos IP, Karakatsani A, Koumarianou A, Tomos PI. Management of surgical lung cancer patients during the COVID-19 pandemic in the financially and resource strained Greek health care system. J Surg Oncol. (2020) 122:124-7. doi: 10.1002/jso.25988 
12. Edirippulige S, Brooks P, Carati C, Wade VA, Smith AC, Wickramasinghe $\mathrm{S}$, et al. It's important, but not important enough: eHealth as a curriculum priority in medical education in Australia. J Telemed Telecare. (2018) 24:697702. doi: $10.1177 / 1357633 X 18793282$

13. Kavoor AR, Chakravarthy K, John T. Remote consultations in the era of COVID-19 pandemic: Preliminary experience in a regional Australian public acute mental health care setting. Asian J Psychiatr. (2020) 51:102074. doi: 10.1016/j.ajp.2020.102074

14. Legido-Quigley $H$, Mateos-García JT, Campos VR, Gea-Sánchez M, Muntaner C, McKee M. The resilience of the Spanish health system against the COVID-19 pandemic. Lancet Public Health. (2020) 5:e2512. doi: 10.1016/S2468-2667(20)30060-8

15. Navarro JC, Arrivillaga-Henríquez J, Salazar-Loor J, Rodriguez-Morales AJ. COVID-19 and dengue, co-epidemics in Ecuador and other countries in Latin America: pushing strained health care systems over the edge. Travel Med Infect Dis. (2020) 37:101656. doi: 10.1016/j.tmaid.2020.101656

16. Rana R-S, Ather MH, Enam SAE. Change in surgical practice amidst COVID 19; example from a tertiary care centre in Pakistan. Ann Med Surg. (2020) 54:79. doi: 10.1016/j.amsu.2020.04.035

17. Requia WJ, Kondo EK, Adams MD, Gold DR, Struchiner CJ. Risk of the Brazilian health care system over 5572 municipalities to exceed health care capacity due to the 2019 novel coronavirus (COVID-19). Sci Total Environ. (2020) 730:139144. doi: 10.1016/j.scitotenv.2020.139144

18. Roder-DeWan S. Health system quality in the time of COVID-19. Lancet Glob Health. (2020) 8:e738-9. doi: 10.1016/S2214-109X(20)30223-0

19. Anderson RM, Heesterbeek H, Klinkenberg D, Hollingsworth TD. How will countrybased mitigation measures influence the course of the COVID-19 epidemic? Lancet. (2020) 395:931-4. doi: 10.1016/S0140-6736(20)30567-5

20. Waris A, Khan AU, Ali M, Ali A, Baset A. COVID-19 outbreak: current scenario of Pakistan. New Microb New Infect. (2020) 35:100681. doi: 10.1016/j.nmni.2020.100681

21. Warsame A, Blanchet K, Checchi F. Towards systematic evaluation of epidemic responses during humanitarian crises: a scoping review of existing public health evaluation frameworks. BMJ Glob Health. (2020) 5:e002109. doi: 10.1136/bmjgh-2019-002109

22. Sahin AR, Erdogan A, Agaoglu PM, Dineri Y, Cakirci AY, Senel ME, et al. 2019 novel coronavirus (COVID-19) outbreak: a review of the current literature. EJMO. (2020) 4:1-7. doi: 10.14744/ejmo.2020.12220

23. Khan S, Khan M, Maqsood K, Hussain T, Zeeshan M. Is Pakistan prepared for the COVID-19 epidemic? A questionnaire-based survey. J Med Virol. (2020) 92:824-32. doi: 10.1002/jmv.25814

24. Kim G, Wang M, Pan H, Neukirch J, Lei D, Hawken-Dennis E, et al. A health system response to COVID-19 in long term care and post-acute care: a threephase approach. J Am Geriatr Soc. (2020) 68:1155-61. doi: 10.1111/jgs.16513

25. Kretchy IA, Asiedu-Danso M, Kretchy JP. Medication management and adherence during the COVID-19 pandemic: perspectives and experiences from LMICs. Res Soc Administr Pharm. (2020) 17:2023-6. doi: 10.1016/j.sapharm.2020.04.007

26. Legido-Quigley H, Asgari N, Teo YY, Leung GM, Oshitani H, Fukuda K, et al. Are high-performing health systems resilient against the COVID-19 epidemic? Lancet. (2020) 395:848-50. doi: 10.1016/S0140-6736(20)30551-1

27. Lorenz C, Azevedo TS, Chiaravalloti-Neto F. COVID-19 and dengue fever: a dangerous combination for the health system in Brazil. Travel Med Infect Dis. (2020) 35:101659. doi: 10.1016/j.tmaid.2020.101659

28. Menon V, Padhy SK. Ethical dilemmas faced by health care workers during COVID-19 pandemic: issues, implications and suggestions. Asian J Psychiatry. (2020) 51:102116. doi: 10.1016/j.ajp.2020.102116

29. Mukhtar S. Pakistanis' mental health during the COVID-19. Asian J Psychiatry. (2020) 51:102127. doi: 10.1016/j.ajp.2020.102127
30. Bagot KL, Cadilhac DA, Vu M, Moss K, Bladin CF, on Behalf of the VST Collaborators. Telemedicine in the acute health setting: a disruptive innovation for specialists (an example from stroke). J Telemed Telecare. (2015) 21:443-8. doi: 10.1177/1357633X15610722

31. Clemensen J, Rothmann MJ, Smith AC, Caffery LJ, Danbjorg DB. Participatory design methods in telemedicine research. J Telemed Telecare. (2017) 23:7805. doi: 10.1177/1357633X16686747

32. Cottrell MA, Hill AJ, O'Leary SP, Raymer ME, Russell TG. Clinicians' perspectives of a novel home-based multidisciplinary telehealth service for patients with chronic spinal pain. Int J Telerehabil. (2018) 10:818. doi: 10.5195/ijt.2018.6249

33. Leite H, Gruber T, Hodgkinson IR. Flattening the infection curveunderstanding the role of telehealth in managing COVID-19. Leadersh Health Serv. (2019) 33:221-36. doi: 10.1108/LHS-05-2020-084

34. Leite H, Hodgkinson IR, Gruber T. New development: 'healing at a distance'-telemedicine and COVID-19. Public Money Manage. (2020) 40:4835. doi: 10.1080/09540962.2020.1748855

35. Smith AC, Thomas E, Snoswell CL, Haydon H, Mehrotra A, Clemensen J, et al. Telehealth for global emergencies: implications for coronavirus disease 2019 (COVID-19). J Telemed Telecare. (2020) 26:309-13. doi: 10.1177/1357633X20916567

36. Abend G. The meaning of 'theory'. Sociol Theor. (2008) 26:173-99. doi: 10.1111/j.1467-9558.2008.00324.x

37. Ravitch SM, Riggan M. Reason and Rigor: How Conceptual Frameworks Guide Research. Pennsylvania: Sage Publications (2017).

38. Uckun FM, Ma H, Zhang J, Ozer Z, Dovat S, Mao C, et al. Serine phosphorylation by SYK is critical for nuclear localization and transcription factor function of Ikaros. Proc Natl Acad Sci USA. (2012) 109:180727. doi: 10.1073/pnas.1209828109

39. Hamzaçebi C, Pekkaya M. Determining of stock investments with gray relational analysis. Expert Syst Appl. (2011) 38:918695. doi: 10.1016/j.eswa.2011.01.070

40. Kuo Y, Yang T, Huang GW. The use of gray relational analysis in solving multiple attribute decision-making problems. Comput Industr Eng. (2008) 55:80-93. doi: 10.1016/j.cie.2007.12.002

41. Tayyar N, Akcanli F, Genç E, Erem I. Evaluating the financial performance of companies operating in the field of informatics and technology registered in BIST by analytical hierarchy process (AHP) and gray relational analysis (TIA) method. Account Finan J. (2014) 61:19-40.

42. $\mathrm{Wu} \mathrm{HH}$. A comparative study of using gray relational analysis in multiple attribute decision making problems. Qual Eng. (2002) 15:20917. doi: 10.1081/QEN-120015853

43. Zhang SF, Liu SY, Zhai RH. An extended GRA method for MCDM with interval-valued triangular fuzzy assessments and unknown weights. Comput Industr Eng. (2011) 61:1336-41. doi: 10.1016/j.cie.2011.08.008

44. Worldometer (2020). Available online at: https://www.worldometers.info/ coronavirus/\#countries (accessed April 8, 2020).

Conflict of Interest: The authors declare that the research was conducted in the absence of any commercial or financial relationships that could be construed as a potential conflict of interest.

Copyright (c) 2021 Qazi, Shaukat, Niazi and Basit. This is an open-access article distributed under the terms of the Creative Commons Attribution License (CC BY). The use, distribution or reproduction in other forums is permitted, provided the original author(s) and the copyright owner(s) are credited and that the original publication in this journal is cited, in accordance with accepted academic practice. No use, distribution or reproduction is permitted which does not comply with these terms. 